\title{
Assessment of Genetic Diversity of Coffee Accessions in Rwanda and Its Implication for Coffee Breeding
}

\author{
B. P. Muvunyi ${ }^{*}$, P. Y. K. Sallah ${ }^{2}$, L. Dusengemungu ${ }^{3}$, Jiyu Zhang ${ }^{1}$ \\ ${ }^{1}$ State Key Laboratory of Grassland Agro-Ecosystems, College of Pastoral Agriculture Science and Technology, Lanzhou \\ University, Lanzhou, China \\ ${ }^{2}$ Faculty of Agriculture, National University of Rwanda, Butare, Rwanda \\ ${ }^{3}$ Lanzhou University of Technology, Lanzhou, China \\ Email: *muvunyi14@lzu.edu.cn
}

How to cite this paper: Muvunyi, B.P., Sallah, P.Y.K., Dusengemungu, L. and Zhang, J.Y. (2017) Assessment of Genetic Diversity of Coffee Accessions in Rwanda and Its Implication for Coffee Breeding. American Journal of Plant Sciences, 8, 2461-2473. https://doi.org/10.4236/ajps.2017.810167

Received: August 3, 2017

Accepted: September 15, 2017

Published: September 18, 2017

Copyright $\odot 2017$ by authors and Scientific Research Publishing Inc. This work is licensed under the Creative Commons Attribution International License (CC BY 4.0).

http://creativecommons.org/licenses/by/4.0/ (c) (i) Open Access

\begin{abstract}
Genetic variation is important in breeding programs because it determines the amount of gain from selection. This study was conducted to determine the magnitude of genetic diversity in coffee (Coffea arabica L.) accessions for developing superior cultivars in Rwanda. Twenty-one coffee accessions established in 1990 in an un-replicated field experiment at the Rubona Experimental Station of the Rwanda Agriculture Board (RAB) located in the mid-altitude zone of Rwanda, were used in the study. Data were recorded on three randomly selected trees on eight quantitative morphological traits in each accession in 2013. One-way analysis of variance (ANOVA) indicated highly significant $(\mathrm{p}<0.01)$ differences among the accessions for number of primary branches, number of leaves per branch, number of cherries per internode and \% coffee leaf rust disease rating; and significant $(\mathrm{p}<0.05)$ for yield, but not for internode length, weight of 100 cherries, and number of internodes per branch. Multivariate analysis showed that the first three principal components contributed cumulatively to $78.3 \%$ of the total variation. The PCA biplot grouped all the accessions into three different clusters and one singleton. The first and second PCs accounted for $43 \%$ and $21 \%$, respectively. Cluster I and II grouped accessions with valuable quantitative agronomic traits while accessions in cluster III exhibited poor agronomic performance. The highest inter cluster distance of 475 was observed between cluster I and II, and the highest intra-cluster distance (62) was in cluster II. The phenotypic markers provided a useful measure of genetic distances among the coffee accessions and identified potential donors for future breeding efforts.
\end{abstract}




\section{Keywords}

Coffee, Genetic Diversity, Morphological Markers, Breeding, Rwanda

\section{Introduction}

Coffee (Coffea Arabica L.) has for long decades been a top cash and export crop in Rwanda. Estimated 500,000 of small-holder farmers cultivate coffee (mainly arabica species) on a total land area of 33,000 ha. However, recently, the productivity in terms of superior quality and yield drastically declined, and this fundamentally stems from the continual widespread cultivation of aged coffee trees with poor adaptation to the current vagaries of climate change, and specifically, to the increasing outbreaks of pests and diseases [1]. For example, twenty-one introduced Coffee germplasm accessions grown at the Coffee experimental station of Rwanda Agricultural Board (RAB), on which this study has been conducted, were introduced from different world coffee collection centers, and represent the main cultivars grown in Rwanda from more than three decades ago. It is thus highly probable that their unsatisfactory performance derives from possible genetic erosion and a shift from their genetic identity due to unstable environments [1].

Intriguingly, these germplasms remarkably exhibit different levels of sensitivity to various abiotic and biotic cues. Yet, the genetic grounds, degree and sources of this divergence remain unknown until now, as there is no extensive genetic diversity analysis responding to this issue that has previously been performed. Awareness of these variations may provide us with the necessary information for selecting the desired economic traits, such as resistance to pests and diseases, as previously stated by [2]. This knowledge is also cherished for a proper management and profitable use of germplasm in breeding programs [3], and it is a pre-requisite for genotype selection [4] [5]. In this view, the government is currently embarking on the rehabilitation project of these germplasm through which evaluating genetic divergence is one of the cornerstones for predicting the best parental lines to incorporate in the future improvement efforts.

Morphological, biochemical, molecular and physiological markers are some of the approaches to estimate genetic diversity among crop species [6]. Far more, morphological evaluation is recognized as the most widely used [7], as it makes it possible to dissect differences among genotypes [8] with less cumbersome and sophisticated techniques, and more importantly, under the actual crop performance conditions. Morphological markers such as seed size and seed per pod and per plants have served to estimate genetic diversity among various plant germplasm [9]. However, results from these eye-guided indicators are more likely to get biased by environment as compared to other markers [10]. Else, morphological markers largely serve to estimate genetic variation in coffee germplasm [3] [11]. [3] also reported of 49 coffee accessions in Ethiopia that significantly differed for the most of the traits studied. Also, [12] was able to detect significant 
genetic variations for the quantitative traits examined across germplasm cultivated in the Southwestern region of Saudi Arabia. Conversely, [11] studied the level of morphological variation between and within new and the existing coffee varieties in Kenya but observed fairly slim genetic variation among these varieties.

Briefly, this study aimed at quantifying the genetic diversity in coffee accessions in Rwanda as a basis for cultivar development and germplasm management in the country. We combined multivariate analysis; including hierarchical cluster analysis and principal component analysis to meet this bid.

\section{Materials and Methods}

The study was carried out at the Rubona Experiment Station (latitude $2^{\circ} 29^{\prime} \mathrm{S}$, longitude $29^{\circ} 46^{\prime} \mathrm{E}, 1650$ masl) of the Rwanda Agriculture Board located in Huye District in the Southern Province of Rwanda from October 2012 to April 2013. A total of 21 coffee accessions established in an un-replicated trial in 1990 were used in the study. The accessions comprised 14 introductions from the Democratic Republic of Congo, four from Ethiopia and three from Kenya (Table 1). These accessions were selected from a total of 183 based on their higher yield potential and widespread use in Rwanda. Quantitative data were collected from 3 coffee trees selected randomly from each accession on number of primary branches, number of internodes per branch, number of leaves per branch, internode length, number of cherries per internode, weight of 100 cherries, number of coffee trees attacked by coffee leaf rust, and yield per tree.

All statistical analyses were performed using GenStat (2007) [13] Discovery Edition 3.0 statistical software and SPSS (2009) version 16 software [14]. Analysis of variance (ANOVA) was computed using the general linear model in GenStat, assuming accession effects were random.

Means for each of eight morphological traits assessed were separated by the least significant difference (LSD) at $\mathrm{p}=0.05$ as suggested by [15]. Phenotypic correlation coefficients were also computed to examine the degree of association among these traits. Principal component analysis of the evaluated accessions was performed according to [16]. Also, genetic distance based on phenotypic characters for all pair-wise comparisons of 21 coffee accessions was determined according to the average intra cluster distance as stated by [17] in the following formula:

$$
D^{2}=\sum \frac{D^{2} i}{N}
$$

Where, $D^{2} i=$ Sum of distances between all possible combinations of accessions included in a cluster, and $N=$ All possible combinations.

\section{Results}

Analysis of variance (ANOVA) for the eight quantitative traits indicated that differences among the accessions were highly significant $(p=0.001)$ for number 
Table 1. Field location and origin of Coffea arabica accessions evaluated in this study.

\begin{tabular}{|c|c|c|c|c|}
\hline $\mathrm{N}^{\circ}$ & Plot no. & Accession name & Abbreviated name & Origin \\
\hline 1 & 2 & Jackson $2 / 1257$ & $\mathrm{~J} 2 / 1257$ & DRC (Mulungu) \\
\hline 2 & 6 & Mibirizi 68-1589 & Mi 68-1589 & DRC (Mulungu) \\
\hline 3 & 8 & Mibirizi 49-1848BV & Mi 49-1848BV & DRC (Mulungu) \\
\hline 4 & 9 & Mibirizi 49-00 & Mi 49-00 & DRC (Mulungu) \\
\hline 5 & 12 & Bourbon Mayaguez 71-2147 & BM 71-2147 & DRC (Mulungu) \\
\hline 6 & 13 & Bourbon Mayaguez 139 & BM 139 & DRC (Mulungu) \\
\hline 7 & 15 & Mysore 175 & MY 175 & DRC (Mulungu) \\
\hline 8 & 16 & Mysore de Mulungu & MY 1105 & DRC (Mulungu) \\
\hline 9 & 18 & Harrar & $\mathrm{Ha}$ & DRC (Mulungu) \\
\hline 10 & 20 & Amphillo & Amp & DRC (Mulungu) \\
\hline 11 & 22 & Ainamba Kaffa & A.K & ETHIOPIA \\
\hline 12 & 28 & Teffari Kella Sidamo & TKS & ETHIOPIA \\
\hline 13 & 31 & Gimma Kaffa & G K & ETHIOPIA \\
\hline 14 & 35 & Population $3303 \mathrm{~N}^{\circ} 21$ & Pop 3303/21 & DRC (Mulungu) \\
\hline 15 & 36 & Population $3303 \mathrm{~N}^{\circ} 22$ & Pop 3303/22 & DRC (Mulungu) \\
\hline 16 & 42 & Mizan Taffari Kaffa & MT K & ETHIOPIA \\
\hline 17 & 62 & Blue Mountain Jamaica 13-1066 & BMJ 13-1066 & DRC (Mulungu) \\
\hline 18 & 67 & Kent 170 & K 170 & DRC (Mulungu) \\
\hline 19 & 69 & K7 (Rwanda) & $\mathrm{K} 7^{\circ}$ & KENYA \\
\hline 20 & 156 & AR 18 & AR 18 & KENYA (Isabu) \\
\hline 21 & 158 & AR 575 & AR 575 & KENYA (Isabu) \\
\hline
\end{tabular}

of primary branches, number of leaves per branch, number of cherries per internode, coffee leaf rust disease, and significant $(\mathrm{p}=0.034)$ for yield. The ANOVA did not show any significant variation in accessions for internode length, weight of 100 cherries, and number of internodes per branch (Table 2).

As shown in (Table 3), the number of primary branches ranged from 63 to 96 , averaging 80 . Over half of the accessions had between 70 and 80 branches and $28.6 \%$ had 81 - 90 branches. The number of leaves per branch averaged 57 and ranged from 15 to 73 . Most of the accessions (66.7\%) had 51 to 70 leaves per branch. The number of cherries per internode averaged 6.5, ranging from 3 to 11 per internode. Most of the accessions (67.2\%) produced 6 to 11 cherries per internode and the remainder had 3 to 5 cherries per internode. Four out of the 21 accessions showed no signs of coffee leaf rust disease, 13 had moderate levels of infection, and 6 had high levels. Cherry yield was below $1.0 \mathrm{t} / \mathrm{ha}$ in all accessions; half of the accessions produced between 200 and $500 \mathrm{~kg} / \mathrm{ha}$ while a proportion of $14.3 \%$ of the evaluated accessions. 
Table 2. Mean squares and their significance levels from the analyses of variance for eight quantitative characters measured in 21 coffee accessions.

\begin{tabular}{|c|c|c|c|c|c|c|c|c|c|}
\hline $\begin{array}{l}\text { Source of } \\
\text { variation }\end{array}$ & $\mathrm{df}$ & $\begin{array}{c}\text { Primary } \\
\text { branches (no.) }\end{array}$ & $\begin{array}{l}\text { Leaves per } \\
\text { branch (no.) }\end{array}$ & $\begin{array}{l}\text { Internodes per } \\
\text { branch (no.) }\end{array}$ & $\begin{array}{l}\text { Internode } \\
\text { length }(\mathrm{cm})\end{array}$ & $\begin{array}{l}\text { Cherries per } \\
\text { internode (no.) }\end{array}$ & $\begin{array}{c}\text { Coffee leaf } \\
\text { rust (\%) }\end{array}$ & $\begin{array}{c}100 \text { cherries } \\
\text { weight }(\mathrm{g})\end{array}$ & $\begin{array}{c}\text { Cherry yield } \\
(\mathrm{kg} / \mathrm{ha})\end{array}$ \\
\hline Accessions & 20 & $405^{\star *}$ & $1171^{* *}$ & 21.4 & 0.26 & $6.1^{* *}$ & $646.7^{\star \star *}$ & 217 & $55044^{*}$ \\
\hline Error & 42 & 106 & 293 & 11.8 & 0.19 & 2.1 & 246 & 490 & 28309 \\
\hline Total & 62 & & & & & & & & \\
\hline
\end{tabular}

Table 3. Mean values of eight quantitative characters measured in the 21 coffee accessions evaluated at Rubona in 2013.

\begin{tabular}{|c|c|c|c|c|c|c|c|c|}
\hline $\begin{array}{c}\text { Number \& } \\
\text { accessions names }\end{array}$ & $\begin{array}{c}\text { Primary } \\
\text { branches (no.) }\end{array}$ & $\begin{array}{l}\text { Leaves per } \\
\text { branch (no.) }\end{array}$ & $\begin{array}{l}\text { Internodes per } \\
\text { branch (no.) }\end{array}$ & $\begin{array}{l}\text { Internode } \\
\text { length }(\mathrm{cm})\end{array}$ & $\begin{array}{l}\text { Cherries per } \\
\text { internode (no.) }\end{array}$ & $\begin{array}{l}\text { Coffee leaf } \\
\text { rust (\%) }\end{array}$ & $\begin{array}{l}100 \text { cherry } \\
\text { weight }(\mathrm{g})\end{array}$ & $\begin{array}{l}\text { Cherry yield } \\
\text { (kg/ha) }\end{array}$ \\
\hline 1) Jackson $2 / 1257$ & 74 & 51 & 26 & 5.1 & 5 & 25.0 & 212.2 & 247 \\
\hline 2) Mibirizi 68-1589 & 73 & 56 & 23 & 5.8 & 9 & 6.3 & 159.6 & 591 \\
\hline 3) Mibirizi 49-1848BV & 70 & 52 & 23 & 5.7 & 7 & 18.8 & 146 & 491 \\
\hline 4) Mibirizi $49-00$ & 74 & 46 & 24 & 5.1 & 7 & 6.2 & 151 & 575 \\
\hline $\begin{array}{l}\text { 5) Bourbon Mayaguez } \\
71-2147\end{array}$ & 71 & 61 & 23 & 5.0 & 7 & 6.25 & 165 & 556 \\
\hline $\begin{array}{l}\text { 6) Bourbon Mayaguez } \\
139\end{array}$ & 90 & 68 & 26 & 5.4 & 7 & 6.25 & 167 & 500 \\
\hline 7) Mysore 175 & 91 & 59 & 22 & 5.0 & 8 & 6.25 & 203 & 603 \\
\hline 8) Mysore de Mulungu & 86 & 73 & 29 & 5.7 & 11 & 0 & 168 & 817 \\
\hline 9) Harrar & 79 & 54 & 25 & 4.8 & 9 & 0 & 161 & 664 \\
\hline 10) Amphillo & 80 & 66 & 25 & 5.1 & 6 & 6.2 & 185 & 309 \\
\hline 11) AinambaKaffa & 88 & 66 & 22 & 6.0 & 6 & 6.25 & 204 & 369 \\
\hline 12) TeffariKella Sidamo & 79 & 65 & 21 & 5.4 & 6 & 12.5 & 153 & 251 \\
\hline 13) Gimma Kaffa & 73 & 39 & 22 & 5.3 & 6 & 6.2 & 184 & 275 \\
\hline $\begin{array}{l}\text { 14) Population } \\
3303 \mathrm{~N}^{\circ} 21\end{array}$ & 86 & 73 & 22 & 5.9 & 7 & 0 & 176 & 640 \\
\hline $\begin{array}{l}\text { 15) Population } \\
3303 \mathrm{~N}^{\circ} 22\end{array}$ & 77 & 64 & 21 & 5.6 & 7 & 0 & 164 & 647 \\
\hline 16) Mizan Taffari Kaffa & 90 & 55 & 24 & 5.3 & 4 & 37.5 & 180 & 224 \\
\hline $\begin{array}{l}\text { 17) BlueMountain } \\
\text { Jamaica 13-1066 }\end{array}$ & 63 & 15 & 19 & 5.3 & 3 & 75 & 151 & 73 \\
\hline 18) Kent 170 & 80 & 69 & 24 & 5.2 & 5 & 56.3 & 180 & 240 \\
\hline 19) K7 & 96 & 50 & 24 & 5.2 & 7 & 6.3 & 202 & 491 \\
\hline 20) AR 18 & 80 & 70 & 24 & 5.2 & 4 & 31.2 & 167 & 219 \\
\hline 21)AR 575 & 77 & 50 & 22 & 5.7 & 6 & 18.7 & 142 & 496 \\
\hline Mean & 80 & 57 & 23 & 5.4 & 6.5 & 15.8 & 172 & 442 \\
\hline $\operatorname{LSD}(0.05)$ & 17 & 28 & ns & Ns & 22.1 & 27.6 & ns & 278 \\
\hline CV (\%) & 13 & 28 & 14.3 & 8.2 & 2.3 & 93.0 & 13.0 & 38.0 \\
\hline
\end{tabular}


A significant $(\mathrm{p}<0.05)$ positive correlation was observed between number of cherries per internode and internode length (Table 4). Number of leaves per branch was positively correlated with number of cherries per internode and number of primary branches. A highly significant $(\mathrm{p}<0.01)$ positive correlation was observed between number of cherries per internode and yield (Table 4). Coffee leaf rust exhibited a highly significant negative correlation with yield and number of cherries per internode and a significant negative correlation with number of leaves per branches (Table 4).

The existence of phenotypic variation among the accessions was further explained by different clusters across the PCA biplot (Figure 1). The PCA grouped the accessions into three clades based on their similarities and differences in terms of the quantitative traits. The first principal component (PC 1) alone contributed $43 \%$ of the total variation, mainly due to yield per tree, coffee leaf rust, number of cherries per internode and number of leaves per branch (Table 5). Characters which contributed to the second principal component (PC 2) accounted for $21 \%$ of the total variation and were dominated by traits such as number of primary branches and weight of 100 cherries. The quantitative characters which showed relatively higher absolute values in the first component were yield per tree, coffee leaf rust, number of cherries per internode and number of leaves per branch (Table 5). Thus, these characters were the main source of the variation in all accessions. The accessions which remained dispersed had larger genetic variability for the traits studied, while accessions and clades which are less scattered in the principal component axes had substantial similarities in the traits evaluated.

The highest inter-cluster distance was 475 and was observed between cluster I and II, followed by I and III clusters (293) and the lowest was observed between II and III clusters (182) (Table 9).

Table 4. Correlations of 8 quantitative traits in 21 coffee accessions evaluated at Rubona in 2013.

\begin{tabular}{|c|c|c|c|c|c|c|c|c|}
\hline Characters & $\begin{array}{l}\text { Primary } \\
\text { branches }\end{array}$ & $\begin{array}{c}\text { Leaves per } \\
\text { branch }\end{array}$ & $\begin{array}{l}\text { Internodes } \\
\text { per branch }\end{array}$ & $\begin{array}{l}\text { Internode } \\
\text { length }\end{array}$ & $\begin{array}{c}\text { Cherries per } \\
\text { internode }\end{array}$ & $\begin{array}{c}\text { Coffee leaf } \\
\text { rust }\end{array}$ & $\begin{array}{c}100 \text { cherries } \\
\text { weight }\end{array}$ & $\begin{array}{c}\text { Cherry } \\
\text { yield }\end{array}$ \\
\hline Primary branches & 1.0 & $0.543^{*}$ & 0.09 & 0.352 & 0.226 & -0.352 & $0.539^{*}$ & 0.258 \\
\hline Leaves per branch & $0.543^{*}$ & 1.0 & $0.451^{*}$ & 0.264 & 0.37 & $-0.473^{*}$ & 0.186 & 0.384 \\
\hline Internode per branch & 0.09 & $0.451^{*}$ & 1.0 & -0.192 & $0.453^{*}$ & -0.156 & -0.14 & 0.204 \\
\hline Internode & 0.352 & 0.264 & -0.192 & 1.0 & 0.138 & -0.287 & 0.213 & 0.336 \\
\hline \multicolumn{9}{|l|}{ Length } \\
\hline Cherries per internode & 0.226 & 0.37 & $0.453^{*}$ & 0.138 & 1.0 & $-0.75^{\star *}$ & -0.08 & $0.9^{* *}$ \\
\hline Coffee leaf rust & -0.352 & $-0.473^{*}$ & -0.156 & -0.287 & $-0.75^{\star *}$ & 1.0 & -0.113 & $-0.75^{\star}$ \\
\hline 100 cherries weight & $0.539^{*}$ & 0.186 & -0.14 & 0.213 & -0.08 & -0.113 & 1.0 & -0.153 \\
\hline Yield & 0.258 & 0.384 & 0.204 & 0.336 & $0.9^{* *}$ & $-0.75^{*}$ & -0.153 & 1.0 \\
\hline
\end{tabular}

${ }^{*},{ }^{*}=$ Significant at $5 \%$ and $1 \%$ levels of probability, respectively. 
Table 5. First three principal components of the 8 quantitative characters in the 21 coffee accessions.

\begin{tabular}{cccc}
\hline & \multicolumn{3}{c}{ Eigenvectors } \\
\hline Characters & PC 1 & PC 2 & PC 3 \\
Number of primary branches & 0.585 & 0.615 & 0.253 \\
Number of leaves per branch & 0.707 & 0.253 & 0.298 \\
Number of internode per branch & 0.216 & -0.31 & 0.85 \\
Internode length (cm) & 0.59 & 0.316 & -0.44 \\
Number of cherries per internode & 0.85 & -0.363 & -0.21 \\
Coffee leaf rust (\%) & -0.84 & 0.169 & 0.014 \\
Weight of 100 cherries (g) & 0.18 & 0.834 & 0.065 \\
Yield (kg/ha) & 0.844 & -0.42 & -0.108 \\
\hline
\end{tabular}

Accessions in the first cluster contributed to the lowest mean value of number of trees attacked by coffee leaf rust, moderate mean yield per tree and highest mean number of leaves per branch, number of primary branches, number of internodes per branch, internode length and number of cherries per internode. The second grouped accessions with the highest mean yield per tree, and moderate mean values of all the other characters. The third cluster grouped accessions the lowest mean value of traits like number of leaves per branch, number of cherries per internode, and yield per tree. Furthermore, this cluster had the highest number of trees attacked by leaf rust. Lastly, the singleton BM Jamaica 13-1066 separated alone within the 21 accessions and was characterized by the lowest number of leaves per branch, number of cherries per internode, and yield per tree; and the highest number of trees attacked by leaf rust.

The pair-wise genetic distances based on the phenotypic traits showed varying genetic distances for the 21 coffee accessions (Table 7). Genetic distances ranging from 0.09 to 5.63 were observed in the pair-wise combinations. The minimum genetic distance of 0.09 was recorded between the $3^{\text {rd }}(\mathrm{MB}$ 68-1589) and the $21^{\text {st }}$ (AR 575) accessions while the highest genetic distance of 5.63 was recorded between the $17^{\text {th }}$ (BM Jamaica 13-1066) and the $8^{\text {th }}$ (M de Mulungu) accessions (Table 7).

\section{Discussion}

The efficient exploitation of germplasm lies in comprehending its genetic difference and elaborating proper relating phenotypical classes [12] [18] [19]. This study sought to determine the genetic diversity in coffee accessions in Rwanda using morphological characterization as a basis for germplasm development and management in Rwanda. The existence of genetic variation in coffee accessions in Rwanda was confirmed, which implies that despites their downsides, morphological markers are still useful for characterizing coffee germplasm as previously stated by [3] [7] [10] and [12]. 
Table 6. Distribution of accessions in four clusters with location.

\begin{tabular}{|c|c|c|c|}
\hline Cluster & Members & Accessions names and respective number & Location \\
\hline \multirow{3}{*}{ I } & \multirow{3}{*}{7} & $\begin{array}{l}\text { Mibirizi 68-1589 (2); Mibirizi 49-1848BV (3); } \\
\text { Mibirizi 49-00 (4); Bourbon Mayaguez 71-2147 } \\
\text { (5); Harrar (9) }\end{array}$ & DRC (Mulungu) \\
\hline & & TeffariKella Sidamo (12) & Kenya \\
\hline & & AR $575(21)$ & Ethiopia \\
\hline \multirow{3}{*}{ II } & \multirow{3}{*}{8} & $\begin{array}{l}\text { Population } 3303 \mathrm{~N}^{\circ} 21 \text { (14); Bourbon Mayaguez } \\
139 \text { (6); Amphillo (10); Mysore de Mulungu (8) }\end{array}$ & DRC (Mulungu) \\
\hline & & K7 (Rwanda) (19) & Ethiopia \\
\hline & & Ainamba Kaffa (11) & Kenya \\
\hline \multirow{3}{*}{ III } & \multirow{3}{*}{5} & Jackson $2 / 1257(1)$ & DRC (Mulungu) \\
\hline & & Mizan Taffari Kaffa (16); Gimma Kaffa (13) & Ethiopia \\
\hline & & AR 18 (20) Kent 170 (18) & Kenya \\
\hline IV (singleton) & 1 & Blue Mountain Jamaica 13-1066 (17) & DRC (Mulungu) \\
\hline
\end{tabular}

(): Accession number.

Table 7. Average intra (bold) and inter cluster distances for the 21 coffee accessions.

\begin{tabular}{cccc}
\hline Cluster & I & II & III \\
\hline I & 37.2 & 475 & 293 \\
II & & 62 & 182 \\
III & & 51.3 \\
\hline
\end{tabular}

The data (Table 3) showed existence of significant morphological variation and, hence, remarkable genetic diversity among the 21 accessions. Adding to this, the study also revealed considerable correlation among the evaluated agronomic traits. Taken together, this information is very instrumental for coffee improvement, particularly during parental selection process. As an example, high yielding and leaf rust resistance accessions were identified, these lines are potential parental donors for further breeding efforts. The significant variation found for the phenotypic traits (number of primary branches, number of leaves, number of cherries per internode, yield and coffee leaf rust) indicated that genetic diversity exists in the Rwandan coffee germplasm. Hence, improvement of accessions through selection and crossing can be practically considered. The morphological variation in Coffea arabica observed in this study agreed with [20] who reported significant differences in coffee accessions for quantitative characters in Ethiopia. This variation among $C$. arabica cultivars may be attributed to a certain degree of out crossing that might have occurred among cultivars as also reported by [21]. However, this was not the case in the Rwandan accessions as they were established from the original collections, but it may due to different impacts of environment on 
the cultivars in the expression of traits. Similar view was reported by [22].

Correlations observed among characters (Table 4) could be used to identify important traits that are desired by coffee breeders [21]. High positive correlation coefficient $(r=0.9)$ observed between number of cherries and yield indicated that both characters share some common genetic information, while traits with negative correlations need careful selection considerations.

The PCA (Figure 1) indicated that yield per tree, coffee leaf rust, number of cherries per internode and number of leaves per branch was the main source of variations in the 21 coffee germplasm. The first three PCA accounted for 78.3\% of the total variation. Moreover, the PCA grouped accessions according to their similarities; closer accessions have a narrow genetic divergence while more scattered accessions have a broader genetic dissimilarity [23]. Similarly, the varying pair-wise genetic distances based on the phenotypic traits also indicated that genetic diversity exists among the 21 coffee accession germplasm and this may accelerate heterotic effect in crosses and a widen the spectrum of variability in segregating generations, as it has been previously asserted by other previous studies [24].

Inter and intra cluster distances are key determinants of genetic divergence, a critical aspect for selecting parents to integrate into hybridization programs [25]. In this study, the observed high inter-cluster (Table 7) distances between cluster I and II showed that crossing of parents across clusters would also facilitate

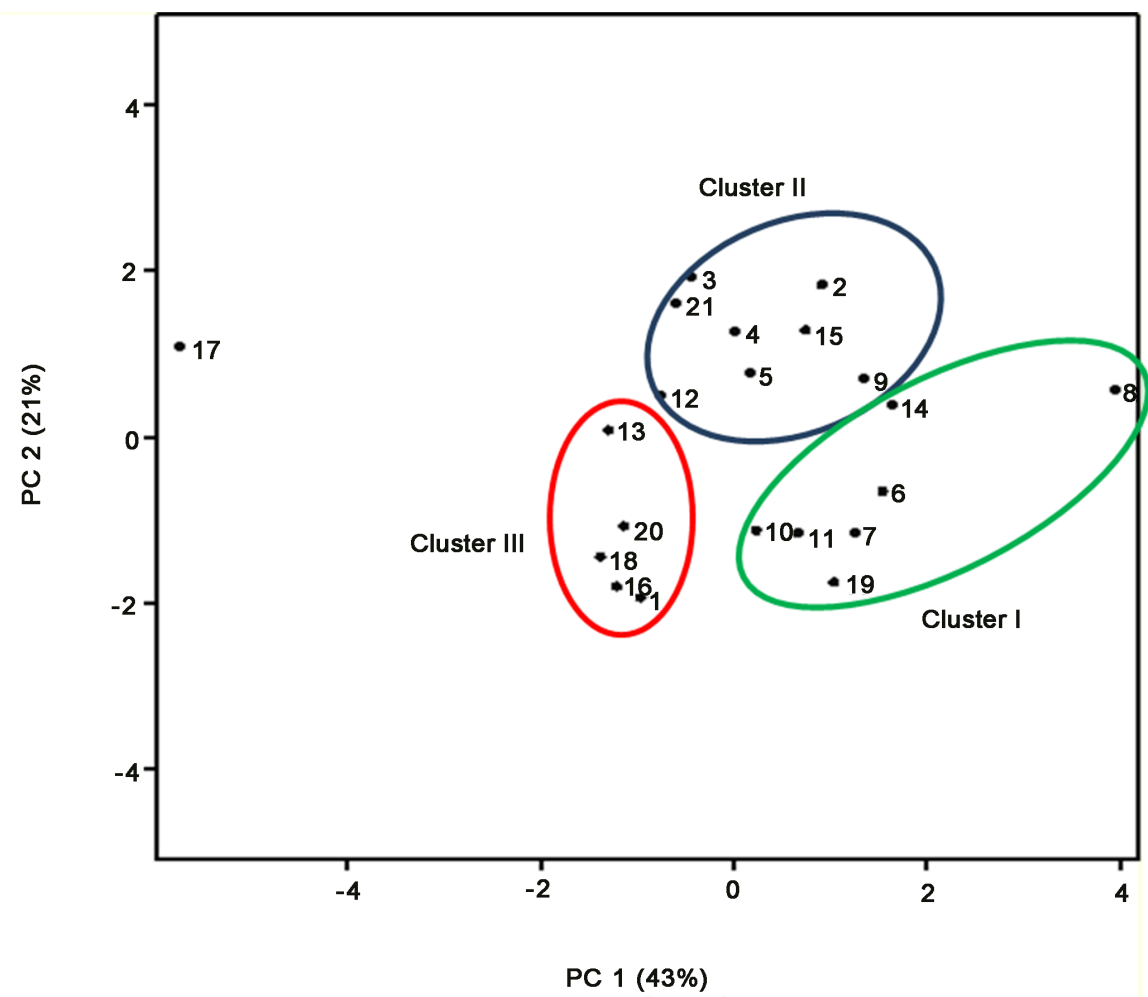

Figure 1. Principal component score plot of PC 1 and PC 2 describing the overall variation among coffee accessions (represented by their respective numbers) within and between different clusters. 
Table 8. Estimates of genetic distance based on phenotypic characters for all pair-wise comparisons of 21 coffee accessions.

\begin{tabular}{|c|c|c|c|c|c|c|c|c|c|c|c|c|c|c|c|c|c|c|c|c|c|}
\hline ID & 1 & 2 & 3 & 4 & 5 & 6 & 7 & 8 & 9 & 10 & 11 & 12 & 13 & 14 & 15 & 16 & 17 & 18 & 19 & 20 & 21 \\
\hline 1 & & & & & & & & & & & & & & & & & & & & & \\
\hline 2 & 1.45 & & & & & & & & & & & & & & & & & & & & \\
\hline 3 & 1.4 & 0.16 & & & & & & & & & & & & & & & & & & & \\
\hline 4 & 1.12 & 0.38 & 0.32 & & & & & & & & & & & & & & & & & & \\
\hline 5 & 0.89 & 0.45 & 0.46 & 0.13 & & & & & & & & & & & & & & & & & \\
\hline 6 & 1.02 & 0.59 & 0.76 & 0.53 & 0.53 & & & & & & & & & & & & & & & & \\
\hline 7 & 0.9 & 1.04 & 1.47 & 0.91 & 0.67 & 0.55 & & & & & & & & & & & & & & & \\
\hline 8 & 2.21 & 0.77 & 1.33 & 1.2 & 1.26 & 0.61 & 1.31 & & & & & & & & & & & & & & \\
\hline 9 & 1.32 & 0.72 & 0.92 & 0.23 & 0.23 & 0.55 & 0.66 & 0.94 & & & & & & & & & & & & & \\
\hline 10 & 0.34 & 0.79 & 0.83 & 0.53 & 0.33 & 0.3 & 0.51 & 1.32 & 0.61 & & & & & & & & & & & & \\
\hline 11 & 1.05 & 0.95 & 1.23 & 1.56 & 1.36 & 0.77 & 0.82 & 1.63 & 1.92 & 0.77 & & & & & & & & & & & \\
\hline 12 & 1.14 & 0.52 & 0.36 & 0.49 & 0.43 & 0.56 & 1.06 & 1.78 & 0.96 & 0.44 & 0.91 & & & & & & & & & & \\
\hline 13 & 0.45 & 0.71 & 0.63 & 0.47 & 0.43 & 0.88 & 0.79 & 2.09 & 0.87 & 0.37 & 0.95 & 0.47 & & & & & & & & & \\
\hline 14 & 1.6 & 0.4 & 0.71 & 0.98 & 0.88 & 0.46 & 0.81 & 0.87 & 1.26 & 0.83 & 0.35 & 0.68 & 1.11 & & & & & & & & \\
\hline 15 & 1.41 & 0.17 & 0.31 & 0.4 & 0.34 & 0.49 & 0.74 & 1.04 & 0.71 & 0.64 & 0.74 & 0.37 & 0.66 & 0.21 & & & & & & & \\
\hline 16 & 0.56 & 1.29 & 1.07 & 0.99 & 0.97 & 0.58 & 0.89 & 2.12 & 1.39 & 0.42 & 0.79 & 0.57 & 0.64 & 1.12 & 1.08 & & & & & & \\
\hline 17 & 2.3 & 2.81 & 1.87 & 2.2 & 2.44 & 3.48 & 3.67 & $5.63^{* *}$ & 3.4 & 2.7 & 3.55 & 1.91 & 1.61 & 3.83 & 2.89 & 1.86 & & & & & \\
\hline 18 & 0.55 & 1.29 & 1.02 & 1.08 & 0.86 & 0.82 & 1.13 & 2.17 & 1.42 & 0.49 & 1.14 & 0.63 & 0.82 & 1.35 & 1.18 & 0.24 & 1.72 & & & & \\
\hline 19 & 0.75 & 1.17 & 1.5 & 0.99 & 0.92 & 0.43 & 0.15 & 1.34 & 0.87 & 0.47 & 0.66 & 1.09 & 0.76 & 0.85 & 0.94 & 0.59 & 3.54 & 1.07 & & & \\
\hline 20 & 0.63 & 1.08 & 0.77 & 0.74 & 0.59 & 0.55 & 1.1 & 2.01 & 1.13 & 0.28 & 1.06 & 0.3 & 0.62 & 1.1 & 0.87 & 0.21 & 1.85 & 0.17 & 0.99 & & \\
\hline 21 & 1.54 & 0.29 & $0.09^{*}$ & 0.36 & 0.56 & 0.66 & 1.36 & 1.49 & 1 & 0.87 & 1.12 & 0.27 & 0.68 & 0.62 & 0.29 & 0.85 & 1.82 & 1 & 1.32 & 0.69 & \\
\hline
\end{tabular}

*,**: Lowest and highest genetic distance, respectively.

transgressive segregation and heterosis maximization. The low inter and intra cluster distances showed close similarities between and within clusters, respectively. The inter-cluster distances were higher than the average intra-cluster distances which mean that accessions between clusters had a higher genetic diversity than accessions within clusters, as it has been also supported by [26].

Genetic diversity oftentimes correlated with the geographic diversity. Yet, the present study indicated that geographical and genetic diversity could not be associated (Table 6). In this view, researches have reported that morphological variation count more than variations in geographic origin, as an evaluator of genetic diversity in coffee [20], due to potential gene flow that might have occurred during the evolutionary history of development and selection procedure that saw some genotypes with new genes that account for the existing heterozygosity among coffee accessions from the same geographic source, a fact that also corroborates 
Table 9. Cluster means of the 8 quantitative traits for the 21 coffee accessions.

\begin{tabular}{lcccc}
\hline & \multicolumn{3}{c}{ Cluster means } \\
\hline Characters & I & II & III & IV (singleton) \\
\hline Number of primary branches & 75.50 & 88.53 & 79.71 & 63.77 \\
Number of leaves per branch & 56 & 65 & 56.8 & 15 \\
Number of internode per branch & 5.39 & 5.47 & 5.23 & 5.26 \\
Internode length & 22.75 & 24.28 & 24 & 19 \\
Number of cherries per internode & 7.25 & 7.42 & 4.8 & 3 \\
Coffee leaf rust & 8.6 & 4.4 & 31.2 & 75 \\
Weight(g) of 100 cherries & 155.2 & 186.74 & 184.8 & 151.5 \\
Yield (kg) & 534 & 533 & 241 & 290 \\
\hline
\end{tabular}

with [27] [28]. Another cause might be the rare random mutation which might have occurred in accessions as previously viewed by [28] [29].

Far more, clusters may be selected also based on agronomic potential. For example, accessions in cluster one (Table 9) should be selected for their high yield potential and cluster two for high resistance to coffee leaf rust in a hybridization program. Accessions in the third cluster exhibited poor agronomic performance; thus, improvement program should target upgrading these accessions. Results from the multivariate analysis both (PCA and hierarchical cluster analysis) were in conformity with the estimated genetic distance (Table 8). For example, the longest genetic distance of 5.63 between the accessions BM Jamaica 13-1066 (17) and Mysore de Mulungu (8) was also detectable from the PAC analysis. Monitoring these variations and correlations will guide us for selecting economic traits, such as resistance to pests and diseases [2].

\section{Conclusion}

Although this study provided huge information on the genetic variation and agronomic performance among different coffee accessions in Rwanda, extending it with more replications across different locations and years may lower possible environmental errors and allow estimating trait heritability index to provide coffee breeders with more reliable information on elite cultivars selection. Also, integrating this work with molecular markers would significantly boost precision breeding as some important variations can't simply be revealed through morphological evaluation.

\section{Acknowledgements}

We are very grateful to the Coffee Research Program of the Rwanda Agriculture Board, Southern Division in Huye District, Rwanda for providing research facilities and funds for this study. We also extend our special thanks to the Faculty of Agriculture, National University of Rwanda for providing research time and resources in support of the study. We greatly thank as well the School of Pastoral 
Agriculture Science and Technology of Lanzhou University for the research training provided under the State Key Laboratory of Grassland Agro-Ecosystems.

\section{Conflict of Interest}

The authors declare that there is no conflict of interest.

\section{References}

[1] Ministry of Finance and Economic Planning of Rwanda, Rwanda Ministry of Agriculture and Animal Husbandry and Ministry of Trade and Industry. (2008) National Coffee Strategy Rwanda 2009-2012.

[2] Allard, R.W. (2002) Principles of Plant Breeding. The Journal of Agricultural Science, 135, 331-334.

[3] Olika, S., Alamerew, K., Kufa, T. and Garedew, W. (2011) Variability of Limmu Coffee (Coffea arabica L.) in Ethiopia. International Journal of Agriculture Research, 6, 482-493. https://doi.org/10.3923/ijar.2011.482.493

[4] FAO (2015) FAO Statistical Pocketbook 2015: World Food and Agriculture. FAO, Rome.

[5] Engles, J.M.M., Rao, V.R., Brown, A.H.D. and Jackson, M.T. (2002) Managing Plant Genetic Diversity. CABI Publishing, Wallingford, 63-107.

[6] Mehmood, S., Bashir, A., Ahmad, A., Akram, Z., Jabeen, N. and Gulfraz, M. (2008) Molecular Characterization of Regional Sorghum bicolor L. Varieties from Pakistan. Pakistan Journal of Botany, 40, 2015-2021.

[7] Geleta, N. and Labuschagne, M.T. (2005) Qualitative Traits Variation in Sorghum (Sorghum bicolor (L.) Moench) Germplasm from, Eastern Highlands of Ethiopia. Biodiversity \& Conservation, 14, 3055-3064. https://doi.org/10.1007/s10531-004-0315-x

[8] Bucheyeki, T.L., Gwanama, C., Mgonja, M., Chisi, M., Folkertsma, R. and Mutegi, R. (2009) Genetic Variability Characterisation of Tanzania Sorghum Landraces Based on Simple Sequence Repeats (SSRs) Molecular and Morphological Markers. African Crop Science Journal, 17, 71-86.

[9] Siise, A. and Massawe, F.J. (2013) Microsatellites Based Marker Molecular Analysis of Ghanaian Bambara Groundnut (Vigna subterranea (L.) Verdc.) Landraces alongside Morphological Characterization. Genetic Resources and Crop Evolution, 60, 777-787. https://doi.org/10.1007/s10722-012-9874-y

[10] Fufa, H., Baenziger, P.S., Beecher, B.S., Dweikat, I., Graybosch, R.A. and Eskridge, K.M. (2005) Comparison of Phenotypic and Molecular Marker-Based Classifications of Hard Red Winter Wheat Cultivars. Euphytica, 145, 133-146. https://doi.org/10.1007/s10681-005-0626-3

[11] Gichimu, B.M. and Omondi, C.O. (2010) Morphological Characterization of Five Newly Developed Lines of Arabica Coffee as Compared to Commercial Cultivars in Kenya. International Journal of Plant Breeding and Genetics, 4, 238-246. https://doi.org/10.3923/ijpbg.2010.238.246

[12] Tounekti, T., Mahdhi, M., Al-Turki, T.A. and Khemira, H. (2017) Genetic Diversity Analysis of Coffee Germplasm Accessions Growing in the Southwestern Saudi Arabia Using Quantitative Traits. Natural Resources, 8, 16.

[13] VSNI. GenStat for Windows. 14th Edition, VSN International, Hemel Hempstead.

[14] SPSS (2009) IBM SPSS Statistics for Windows. Version 16.0, IBM Corp., Armonk. 
[15] Gomez, K.A. and Gomez, A.A. (1984) Statistical Procedures for Agricultural Research. Wiley, New York.

[16] Chahal, G. and Gosal, S.S. (2002) Principles and Procedures of Plant Breeding: Biotechnological and Conventional Approaches. Narosa Publishing House, New Delhi, Vol. 21, 64-89.

[17] Singh, R.K. and Chaudhary, B.D. (1985) Biometrical Method in Quantitative Genetics Analysis. Kalyani Publishers, New Delhi.

[18] Beer, S.C., Goffreda, J., Phillips, T.D., Murphy, J.P. and Sorrells, M.E. (1993) Assessment of Genetic Variation in Avena sterilis using Morphologicall Traits, Isozymes, and RFLPs. Crop Science, 33, 1386-1393. https://doi.org/10.2135/cropsci1993.0011183X003300060051x

[19] Beuselinck, P.R. and Steiner, J.J. (1992) A Proposed Framework for Identifying, Quantifying, and Utilizing Plant Germplasm Resources. Field Crops Research, 29, 261-272.

[20] Bellachew, B. and Labouisse, J.-P. (2007) Arabica Coffee (Coffea arabica L.) Local Landrace Development Strategy in Its Center of Origin and Diversity. 21 st International Conference on Coffee Science, Montpellier, 11-15 September 2006, 818-826.

[21] Tran, T.M.H. (2005) Genetic Variation in Cultivated Coffee (Coffea arabica L.) Accessions in Northern New South Wales, Australia. Thesis Submitted for the Fulfillment of the Requirements for the Degree of Master of Science at Southern Cross University, 73-89.

[22] Ramos, L.C.D.S. and Carvalho, A. (1997) Shoot and Root Evaluations on Seedlings from Coffea Genotypes. Bragantia, 56, 59-68. https://doi.org/10.1590/S0006-87051997000100006

[23] Obeng-Antwi, K., Craufurd, P., Menkir, A., Ellis, R.H. and Sallah, P.Y.K. (2011) Intra-Landrace Variability of Two Landraces in Ghana. International Journal of Science and Advanced Technology, 1-37.

[24] Ahmed, A.U., Sarker, M.A., Choudhury, J.A., Ara, N. and Ali, M.M. (2002) Genetic Divergence Analysis in Chickpea. Bangladesh Journal of Agricultural Research, 27, 47-50.

[25] Peeters, J.P. and Martinelli, J.A. (1989) Hierarchical Cluster Analysis as a Tool to Manage Variation in Germplasm Collections. Theoretical and Applied Genetics, 78, 42-48. https://doi.org/10.1007/BF00299751

[26] Rahman, M. and Al Munsur, M. (2010) Genetic Divergence Analysis of Lime. Journal of the Bangladesh Agricultural University, 7, 5. https://doi.org/10.3329/jbau.v7i1.4795

[27] Esayas, A. (2005) Molecular Genetic Diversity Study of Forest Coffee Tree (Coffea arabica L.) Population in Ethiopia: Implications for Conservation and Breeding. PhD Thesis, Swedish University of Agriculture Science, 87-103.

[28] Udupa, S. and Baum, M. (2001) High Mutation Rate and Mutational Bias at (TAA)n Microsatellite Loci in Chickpea (Cicer arietinum L.). Molecular Genetics and Genomics, 265, 1097-1103. https://doi.org/10.1007/s004380100508

[29] Vigouroux, Y., Jaqueth, J.S., Matsuoka, Y., Smith, O.S., Beavis, W.D., Smith, J.S. and Doebley, J. (2002) Rate and Pattern of Mutation at Microsatellite Loci in Maize. Molecular Biology and Evolution, 19, 1251-1260.

https://doi.org/10.1093/oxfordjournals.molbev.a004186 
Submit or recommend next manuscript to SCIRP and we will provide best service for you:

Accepting pre-submission inquiries through Email, Facebook, LinkedIn, Twitter, etc. A wide selection of journals (inclusive of 9 subjects, more than 200 journals)

Providing 24-hour high-quality service

User-friendly online submission system

Fair and swift peer-review system

Efficient typesetting and proofreading procedure

Display of the result of downloads and visits, as well as the number of cited articles Maximum dissemination of your research work

Submit your manuscript at: http://papersubmission.scirp.org/

Or contact ajps@scirp.org 